\title{
Applying Geographic Information System Methodologies to Estimate the Catchment Area Accessibility of Park-and-Ride Facilities
}

\author{
Jairo Ortega ${ }^{1 *}$, János Tóth¹, Tamás Péter² \\ 1 Department of Transport Technology and Economics, Faculty of Transportation Engineering and Vehicle Engineering, Budapest \\ University of Technology and Economics, H-1111 Budapest, Müegyetem rkp. 3, Hungary \\ 2 Department of Control for Transportation and Vehicle Systems, Faculty of Transportation Engineering and Vehicle Engineering, \\ Budapest University of Technology and Economics, H-1111 Budapest, Múegyetem rkp. 3, Hungary \\ ${ }^{*}$ Corresponding author, e-mail: jortegaortega@edu.bme.hu
}

Received: 04 May 2020, Accepted: 23 August 2021, Published online: 14 December 2021

\begin{abstract}
Park and Ride (P\&R) systems play a potentially important role in transportation planning to decrease the undesirable effects of private cars in the Central Business District (CBD). In order to achieve this objective, an essential component to be investigated is the catchment areas of these P\&R facilities. However, a limited number of studies have applied the Geographic Information System (GIS) to study the spatial boundary accessibility of the catchment areas of P\&R. This study aims to analyze the spatial boundary accessibility of the catchment areas of P\&R facilities using three GIS methods. The first method uses geometric shapes to analyze the catchment areas of P\&R facilities according to regular shapes, such as parabolas or circles. The market area is the second method used to analyze travel time via the tool ArcGIS Network Analyst to determine the catchment area of P\&Rs. Finally, the dynamic accessibility method determines how accessible a facility can be through a study of the spatial boundary accessibility of P\&Rs based on the travel time and distance between zones and $P \& R$. The result shows that the static methods identify the spatial boundary accessibility through the calculation of the size of the shape of each P\&R separately, while the dynamic method identifies the level of accessibility in detail for all P\&R and also the accessibility of each zone to reach a facility. In conclusion, the dynamic accessibility method presents better accuracy than static methods in order to estimate the spatial boundary accessibility of the catchment area of P\&Rs.
\end{abstract}

Keywords

land use, trip starting locations, Park and Ride, traffic

\section{Introduction}

Commuters and private vehicle users can travel inter-city or intra-city by covering a certain distance in their private vehicle, leaving their vehicle at a parking location close to a public transport station, and travelling the rest of the distance using public transport. This type of facility is called a Park and Ride (P\&R) and allows travelers to travel using public and private transport to minimize their travel expense conveniently. These facilities are located in different parts of cities to aid travelers. This transport planning system is a medium-term solution for sustainable development, as it streamlines the use of public transport. The set-up of a P\&R system requires fine-tuning of the seting and location, design, assessment, and monitoring of the systems to increase the number of sites that are used by people to maximize their utilization and thus their impact in reducing air pollution and traffic (Noel, 1988). P\&R systems have practically resulted in a significant shift from private vehicle travel to public transport, making them an effective tool for sustainable travel and mobility plans (Cairns, 1998; Ortega et al., 2019; Tang and Lee, 2016).

The essential feature that P\&R systems provide to planners is accessibility. This accessibility can be measured by the catchment area, which is defined as the convenience by which locations can be traversed using any travel model. The catchment area depends on the distribution of destinations from the starting points of different travelers. Moreover, it refers to zoning, the parking capacity of the P\&R facility, the location of the public transport service, 
and road alignments, each of which affects the accessibility of usage (Debrezion et al., 2009; Fan et al., 1993; Saif et al., 2019; Young and Blainey, 2018). Catchment area assessment is a fundamental prerequisite for the planning of $P \& R$ systems, which depend on the latent demand. There are numerous methods for estimating the shape and size of the catchment area, each with a different level of sophistication and ease of calculation. The hoice of the estimation model depends on the complexity of the factors, the computational software, and the data that can be used for the estimation.

A number of studies have analyzed catchment areas, but those researches have not determined the spatial boundaries of $P \& R$ catchment areas. The present study aims to examine the spatial boundaries of P\&R catchment areas by using the geometric shape approach, the market area approach, and the dynamic accessibility approach. The first approach utilizes two means for the calculation of the catchment area: a parabola and a circle. The market area analyses travel time using the ArcGIS Network Analyst (Esri, a; Zagel, 2006) within the Geographic Information Systems (GIS) software (Esri, b). The dynamic accessibility approach to catchment area of $P \& R$ determines how accessibility can reach users from several areas. The contributions of this study are summarized in the following points:

1. This study provides a useful guide to determine the spatial boundaries of the catchment areas of P\&Rs.

2. It provides three research approaches to calculate the catchment area: a geometric shape, a market area, and dynamic accessibility.

3. It provides a comparative approach for the principal characteristics of each method.

The rest of this study is structured as follows: Section 2 provides a relevant literature review approach. Section 3 provides an interpretation of the methods employed to calculate the catchment area of P\&R facilities (geometric shape, market area, and dynamic accessibility). Section 4 presents a case study for the methods previously described and a brief description of the data and the context for its collection. Section 5 explains the results of the tables and their representation in the GIS software. In the conclusion section, the authors emphasize the novelty of this approach, the results, the limitations, and ideas for future research.

\section{Literature review}

The catchment area of a $\mathrm{P} \& \mathrm{R}$ system is a vital component for calculating its demand and accessibility and can also be used to study alternative P\&R locations in a city
(Mesa and Ortega, 2001). Catchment areas vary in size, depending on different factors like the transit network, congestion within the P\&R facility, and the location of the facility itself (Spillar, 1997). Different approaches are used to calculate the catchment area: mathematical models, geographical models, or a merger of both (Syed Adnan and Kadar Hamsa, 2013). Assuming that the geometric shape of the catchment area is a circle or a parabola can help with the development of its mathematical model (Turnbull, 1995), which provides the shape of the P\&R facility using mathematical equations. GIS is a system that allows one to integrate, organize, and analyze spatial data to visualize patterns and relationships. GIS integrates different kinds of data layers, using spatial location, and visualizes these data into maps. These maps can be easily imbedded in different apps and can thus be integrated with other systems. Due to this effectiveness, GIS has become a widely popular technology for carrying out different research activities that are rooted in the science of geography. It has, for instance, been used to precisely describe retail store trade areas. However, GIS has rarely been used to analyze the catchment areas of P\&R systems. With the use of GIS, it would be possible to extract highly accurate information on the catchment areas of P\&R facilities, which can then be analyzed with several techniques.

Outlining of the catchment area is necessary for transport planning. This outlining helps mark the spatial areas for travelers of any P\&R facility and its properties, like travel distance and travel time. The catchment area, based on this approach, can be calculated using its geographical shape (Stieffenhofer et al., 2016; Yajing et al., 2013). The geographical-shape method is a geographical method of study used to understand a catchment area (Duncan and Christensen, 2013). Existing demand characteristics can also be used to calculate the catchment area. The boundary of the area can also be formulated using travel costs, time, and fees (Cornejo et al., 2014; Zijlstra et al., 2015). This is done by collecting data with a P\&R survey to help identify the market size of an area for different facilities. This generates a detailed, sophisticated analysis of the catchment area of the P\&R system. The area's extent is represented by GIS software. If the data are available, refining, or developing the area's extent becomes relatively simple.

The market area method, also called a geographic study of the catchment area, uses the area within which users of a P\&R come to the facility based on transport parameters such as travel time and distance (Duncan and Cook, 2014); additionally, the market area can be calculated through 
existing demand characteristics. A similar approach, conducted by Fang et al. (2017) and Farhan and Murray (2005), delineates the boundary around a market area on the basis of travel costs, travel time, and usage fees. The author developed a P\&R survey to identify the sizes of market areas for different types of P\&R facilities. The result was a detailed analysis of the catchment area of the P\&R system. GIS represents the degree to which a market area extends. If data on P\&R locations are available, delimiting the extent of an area can be relatively simple. However, this area is one of the more difficult elements in the P\&R system. Moreover, there is an underlying problem; these approaches do not take different levels of dynamic accessibility into account (Liu et al., 2009; Yang and Wang, 2002).

A catchment area is classified using two methods, static methods (as mentioned above) and dynamic methods. Dynamic accessibility is the study of the interactions between the travelers and locations of the facilities based on real-time. Detailed research on dynamic accessibility should include a quantitative analysis of the location(s) in which the P\&R facility or facilities is located, transport modes, and measurements of traffic and distance (Farhan and Murray, 2008). Herein, the principal attribute is the incorporation of traffic parameters in real-time, resulting in a more precise method for calculating the accessibility of a P\&R facility. A significant contribution was made by Carlson and Owen (2019). Through their investigations, the authors studied the accessibility of P\&R using an algorithm where the starting trip points are determined based on the land use parameter, and the P\&R facilities are the destination points. Hence, the algorithm calculates the travel time from the origin to the destination point based on three traffic metrics. Furthermore, the P\&R potential demand is calculated based on the user's preference to choose a facility (Tam and Lam, 2000; Li et al., 2007). The data that are needed to create this dataset for any geospatial application are easily accessible with various web applications. One of these web applications is Google Maps, which allows users to look up geographical locations. With the help of the Google API, Google web applications can be integrated with other services, such as GIS. By integrating these two programs, GIS can use the data of Google Maps to estimate the travel time between two points. Travel time is usually used as an indicator for ease of access. Without integration into Google Maps, the GIS analysis would need large amounts of fundamental geographical data to create origin-destination (OD) matrices (Bahoken and Olteanu-Raimond, 2013; Cao et al., 2019;
Ma et al., 2013; Xiang and Wu, 2019; Xu et al., 2019). Obtaining a travel time matrix of sometimes more than one thousand routes is a significant challenge for researchers. However, by integrating a web mapping platform, like Google Maps or OpenStreetMap (OSM), GIS can be provided information on existing transport networks. In this way, GIS is able to perform a stronger spatial analysis by integrating into an application like Google Maps, where it can directly accurately estimate travel time with related distances and routes from the Google Maps interface. Another advantage of integrating GIS with a mapping platform is that it becomes possible to look at the relationship between multiple traffic factors and the resulting travel costs, including fundamental traffic flow principles and historical traffic data. Therefore, the integration of GIS with these open-access web mapping data can simplify the study of dynamic accessibility See et al., 2013; Veenendaal, 2016; Veenendaal et al., 2017).

This study aims to calculate the catchment area of P\&R facilities via the geometric shape, market area, and dynamic accessibility approaches. The geometric shape approach offers two ways to calculate the catchment area of P\&R facilities: a parabola approach and a circle approach. A second research approach used to calculate the catchment area of P\&R facilities is the market area method, whose principal component travel time is analyzed using a tool called ArcGIS Network Analyst (Zagel, 2006) within the Geographic Information Systems (GIS) software (Esri, b). In both methods, the geometric shapes and market areas are compared with the entire area and its coverage zone around the facility. Finally, a novel dynamic accessibility method is used to determine how dynamically accessible a facility could be to catch potential users and how far it is from alternative facilities.

\section{Research methodology}

As discussed previously, there are few existing researchers on the characteristics of the catchment area of the P\&R system, such as the area's extent, travel time, and distance.

\subsection{Geometric shape method}

The geometric shape method is a static method with two sub-approaches in which parabolic and circular shapes are used to determine the area of influence of each P\&R facility.

This approach delineates boundaries based on the following three steps:

1. Define a parabola by surrounding the P\&R facility oriented towards principal network access. For the 
circle method, the center of the circle is the coordinates of the location of the facility.

2. Determine the maximum reachable distance of the P\&R facility.

3. Calculate the extent of the catchment area.

Different studies have assumed parabolic or circular shapes (Gutsche et al., 2020) to represent the catchment areas for P\&R facilities, which may be attributed to the fact that such shapes represent a user's tendency to drive to a P\&R facility if it is located in their direction of travel. Hanjoul et al. (1988) described parabolas and circles to be the most useful geometric shapes due to their homogeneous areas. Spillar et al. (1999) showed that a clear description using geometric shape method delineation approaches combined with the use of GIS offers the ability to implement such methods relatively simply. This paper utilized GIS-based functionality for examining and visualizing the catchment areas of P\&R.

\subsubsection{Parabola method}

The steps and equations used to calculate the area extent of the parabola and represent in GIS are the following:

Step 1. Define a parabola by surrounding the P\&R facility oriented towards principal network access. A minor complicating feature of the associated parabola in practice is that a P\&R facility is not likely to be horizontal or vertical, as the parabola can be rotated around the location of the P\&R facility toward the user's travel direction, in other words, in the direction of the main road access of the facility (Ison and Mulley, 2014).

Step 2. Determine the maximum reachable distance of the $P \& R$ facility. As noted previously, the parabolic catchment area approach assumes that users have the same degree of accessibility to the facility. Then, determine parameters $p$ in Eq. (1) and Eq. (2), which represent the distance from the vertex $(h, k)$ to the focus $(h, k+p)$ (Fig. 1) - in other words, the distance users are willing to travel to reach a facility. Vertexes $(h, k)$ are the coordinates of the P\&R location determined by ArcGIS.

The following equations represent a parabola:

$$
\begin{aligned}
& (x-h)^{2}=4 p(y-k), \\
& (y-k)^{2}=4 p(x-h) .
\end{aligned}
$$

\section{As we can see in Fig. 1:}

1. Rotated about the location of the P\&R facility toward the user's travel direction or major road;

2. $h, k$ are the coordinate of the P\&R location;

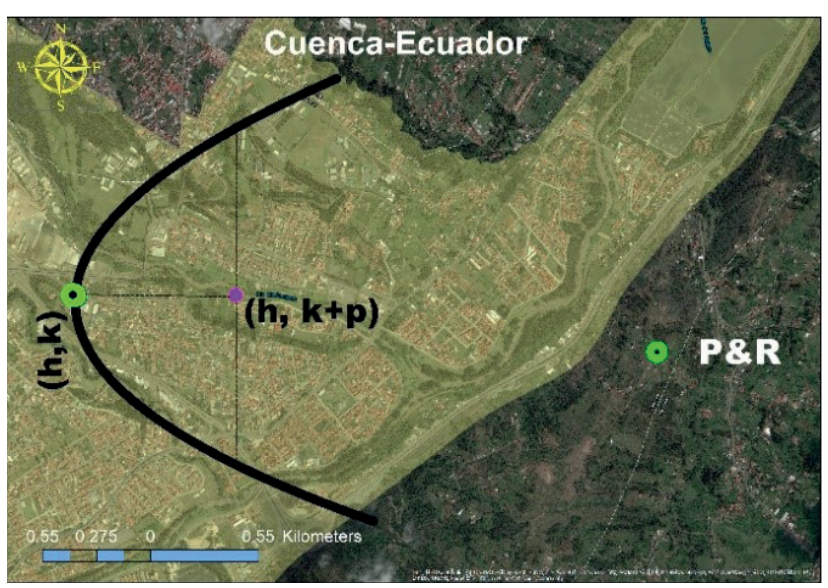

Fig. 1 A graph of the parabola components

3. $p$ represents the distance from the vertex $(h, k)$ to the focus $(h, k+p)$, which is the distance that users are willing to reach a facility [22];

4. Data: $(h, k)=(2.8,78), p=2000 \mathrm{~m}$;

5. Equations: $(x-2.8)^{2}=8000(y-78)$,

$$
(y-78)^{2}=4 p(x-2.8) \text {. }
$$

The difference between Eqs. (1) and (2) is that Eq. (1) is oriented around the y-axis, and Eq. (2) is oriented around the x-axis. Essentially, both equations can be used, and the parabola will be oriented towards the principal network access.

Step 3. Calculate the extent of the catchment area. This method calculates the area of the parabola using the command "calculate geometry" in the ArcGIS software.

Additionally, our method is a general approach of the use of parabola equations in which the maximum distance and travel time are defined as each suitable point of the boundary area. This area defines the catchment area, and also is considered as suitable parking lots of the P\&R system.

\subsubsection{Circle method}

The steps and equations used to calculate the area extent of the circle and represent it in GIS are the following:

Step 1. Define the circle surrounding the $P \& R$ facility. The center of the circle indicates the coordinates of the location of the facility.

Step 2. Determine the maximum radial distance to the facility. This approach is based on the literature and assumes that users have the same degree of accessibility to the facility. The maximum length of the radius can be between $1 \mathrm{~km}$ and $3 \mathrm{~km}$. The value of the distance depends on the result of the survey developed by Vincent (2007), based on peoples' willingness to use P\&R Systems. 
Step 3. Identify the catchment area. This method calculates the area of the circle using the command "calculate geometry" in the ArcGIS software.

$(x-h)^{2}+(y-k)^{2}=r^{2}$,

where $r$ represents the distance from the P\&R location to the maximum catchment area, which is the most reachable distance that users are willing to travel to reach a facility, and $h, k$ indicates the coordinates of the location of the P\&R.

\subsection{Market area method}

The market area method uses GIS software and the ArcGIS Network Analyst extension to calculate market areas, which are spatially represented as irregular polygons whose boundaries include the travel time from the closest road network to a Park \& Ride facility. A market area is a surface over which a demand offered at a specific location is expressed, thereby generating a spatial dimension with the necessary data, such as distances or travel times from the P\&R facility to urban zones. A market area is relatively simple to calculate with a reasonable level of accuracy. The GIS software and the ArcGIS Network Analyst extension have become fundamental tools to calculate market areas (Zagel, 2006). For instance, a network service area is a region that encompasses all accessible streets to reach the facility in a measured time. This method is based on the parameter travel time, and its results describe a better level of accuracy than the geometric shape method. The Table 1 describes how to calculate the catchment area of a P\&R system via the market-area method.

Table 1 Steps for calculating the catchment area of the P\&R by the market-area method

\begin{tabular}{|c|c|c|}
\hline \multicolumn{3}{|r|}{ Calculation of the market-area for each P\&R facility } \\
\hline Input & & $\begin{array}{l}\text { City zone spatial data, P\&R location data, set of road } \\
\text { network data. }\end{array}$ \\
\hline Output & & Market-area for each facility. \\
\hline \multirow[t]{6}{*}{ Steps } & 1 & $\begin{array}{l}\text { Create a network dataset in a geodatabase using } \\
\text { Cuenca streets. }\end{array}$ \\
\hline & 2 & $\begin{array}{l}\text { Active the Network Analyst window for the road } \\
\text { network data in ArcGIS. }\end{array}$ \\
\hline & 3 & Load the location of the P\&R facilities' shapes. \\
\hline & 4 & Setting up the parameter travel time for the analysis. \\
\hline & 5 & $\begin{array}{l}\text { Run the process to compute and generate polygons for } \\
\text { each facility. }\end{array}$ \\
\hline & 6 & $\begin{array}{c}\text { The outer and inner service area breaks switch colors, } \\
\text { thus clarifying which areas the travel time minute } \\
\text { breaks cover. }\end{array}$ \\
\hline
\end{tabular}

\subsection{Dynamic accessibility method}

The dynamic accessibility method determines the level of accessibility measured over a period of time. In other words, it determines how dynamically accessible a facility could be to catch potential users and how far it is from alternative facilities. The Google Maps Directions API Service provides information about a route. A route is obtained from an initial location to a specific destination for different transport modes and travel times. The Directions Service calculates the traffic conditions with no traffic, low traffic, and high traffic. This method is based on non-real-time data, but on average traffic situation in the mentioned three situations. Finally, dynamic accessibility is interpreted for a set of graphs of travel time and distance. The dynamic method solves the limitations of the static methods mentioned above and adds a set of parameters to a comprehensive analysis of the catchment area of the P\&R system. The following steps allow one to develop a dynamic accessibility method:

1. Determine the origin coordinates of potential trips to the $P \& R$.

2. Determine the P\&R facility coordinates, which are considered the destination points.

3. Calculate the nearest $P \& R$ facility in the network.

4. Calculate the travel time and accessibility level for each zone.

\section{Case study}

This section describes our case study in Cuenca, Ecuador, which is located in the Andes mountains about 2.660 meters high; its urban population is 329.928 . Cuenca is categorized as a UNESCO World Heritage Site because of its historical monuments. The city center is considered a Central Business District (CBD) with a high number of private cars, which generates traffic congestion and air pollution. The local transport authorities have developed an Urban Sustainable Mobility Plan (SUMP) to provide a set of well-organized instructions on how to develop efficient, safe, and environmentally friendly mobility solutions for the inhabitants of modern urban environments. Therefore, the Sustainable Urban Mobility Plans (SUMP) method includes a set of detailed transport parameters for parking policies.

\subsection{Data}

The SUMP provides the following data and metrics: Table 2 shows the extent of the area of each zone. Table 3 by Ortega et al. (2019) identifies a set of parameters for the 
Table 2 Value of the area of each zone in Cuenca-Ecuador

\begin{tabular}{lccccc}
\hline ZONE & $\begin{array}{c}\text { AREA } \\
\left(\mathrm{km}^{2}\right)\end{array}$ & ZONE & $\begin{array}{c}\text { AREA } \\
\left(\mathrm{km}^{2}\right)\end{array}$ & ZONE & $\begin{array}{c}\text { AREA } \\
\left(\mathrm{km}^{2}\right)\end{array}$ \\
\hline 1 & 9.5 & 6 & 0.74 & 11 & 6.46 \\
2 & 3.4 & 7 & 1.22 & 12 & 3.2 \\
3 & 11.2 & 8 & 1.13 & 13 & 3.3 \\
4 & 5.28 & 9 & 2.61 & 14 & 5.1 \\
5 & 0.6 & 10 & 4.03 & 15 & 15.7 \\
\hline & & Table 3 Location for each P\&R & \\
\hline ID & P\&R & Latitude & Longitude & N lots \\
\hline A & Control Sur & -2.923399 & -79.0382343 & 1603 \\
B & Banos & -2.9147923 & -79.038227 & 1002 \\
C & Feria Libre & -2.8956061 & -79.0268517 & 2917 \\
D & Canirabamba & -2.9066296 & -79.0293574 & 1170 \\
E & Totoracocha & -2.897063 & -78.9902306 & 2216 \\
F & Aeropuerto & -2.8861158 & -78.9929826 & 1475 \\
G & Parque Industrial & -2.881886 & -78.9776599 & 3369 \\
\hline & & & &
\end{tabular}

seven P\&Rs (A-G) in Cuenca, Ecuador, such as the number of lots in each P\&R facility, and P\&R location.

\section{Conducted results}

\subsection{Geometric shape}

The geometric shape method represents the catchment area of the P\&R system. Fig. 2 and Table 4 show the parabola method results, while Fig. 3 and Table 4 show the circle method with two distance values (1 km and $3 \mathrm{~km})$.

Table 4 shows the numerical results of the catchment area for each $P \& R$ facility using the geometric shape method. The results of the calculation of the catchment area of P\&R (A) depend on the type of method used-for example, $1.63 \mathrm{~km}^{2}$ for the parabola method and $1 \mathrm{~km}^{2}$ and $3 \mathrm{~km}^{2}$ for the circle method.

\subsection{Market area}

The market area method uses the GIS with the ArcGIS Network Analyst extension. The network characteristics and the travel time from an urban area point to the P\&R facility is provided for the Cuenca municipality by the GIS file. The market area was relatively simple to determine with the network analyst tool, and the boundary of the irregular polygons is drawn under the parameter travel time network. The area extent of the catchment area, which depends on the area of the shape, is calculated by the ArcGIS Network Analyst extension (Fig. 4).

Table 5 shows the numerical results of the study of the catchment area for each P\&R facility using the market

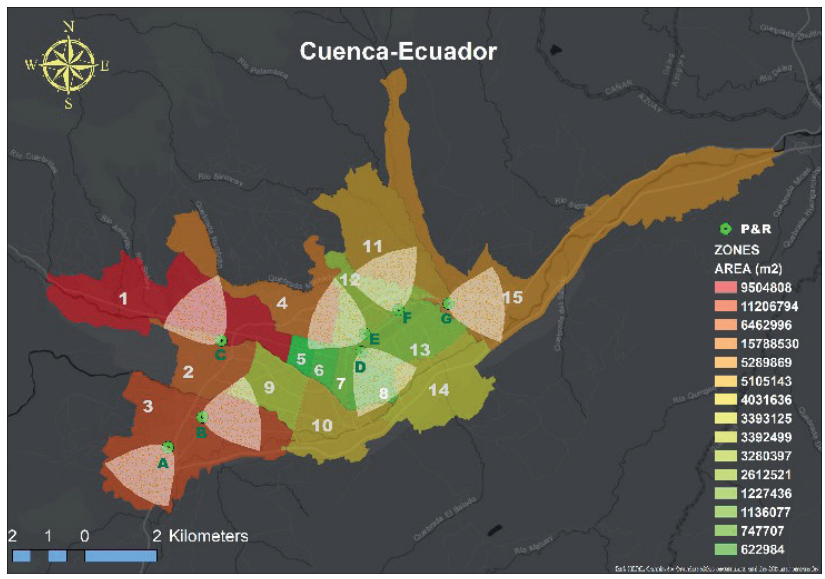

Fig. 2 Geographic information systems representation of the parabola method

Table 4 Numerical results of the geometric shape method

\begin{tabular}{lccccc}
\hline ID & \multicolumn{2}{c}{ Parabolic } & \multicolumn{3}{c}{ Circle } \\
P\&R & $\begin{array}{c}\text { Catchment } \\
\text { area km }\end{array}$ & $\begin{array}{c}\text { Influence } \\
\text { Zones }\end{array}$ & $\begin{array}{c}\text { Catchment } \\
\text { area km }{ }^{2}\end{array}$ & $\begin{array}{c}\text { Catchment } \\
\text { area km }{ }^{2}\end{array}$ & $\begin{array}{c}\text { Influence } \\
\text { Zones }\end{array}$ \\
\hline A & 1.63 & 3 & 1 & 3 & 3 \\
B & 2.01 & 3 & 1 & 3 & 3 \\
C & 2.78 & 1 & 1 & 3 & 1,2 \\
D & 2.85 & 7,8 & 1 & 3 & 7,8 \\
E & 2.62 & 4,12 & 1 & 3 & 12 \\
F & 2.94 & 11,12 & 1 & 3 & 13 \\
G & 2.41 & 15 & 1 & 3 & 15 \\
\hline
\end{tabular}

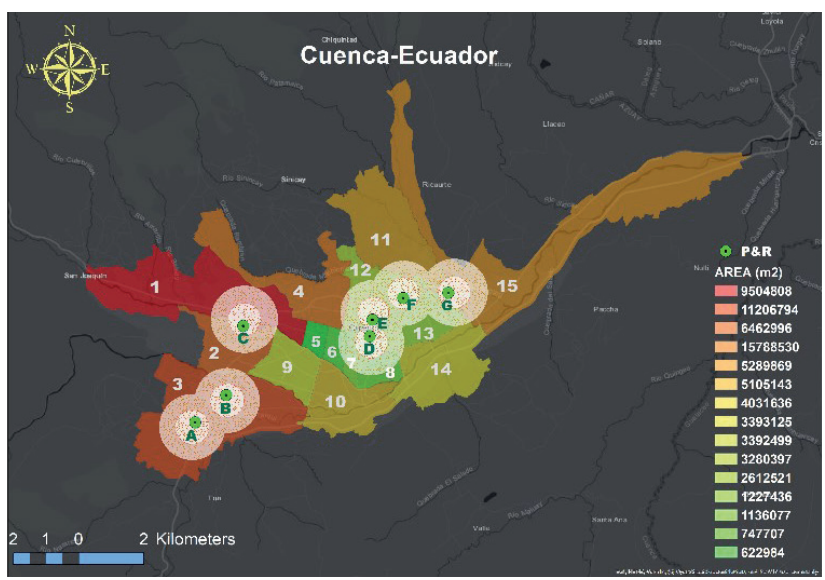

Fig. 3 Geographic information systems representation of the circle method

area method. The result for the area extent of the P\&R (A) is $0.59 \mathrm{~km}^{2}$ for a travel time of 5 minutes and $1.39 \mathrm{~km}^{2}$ for a travel time of 10 minutes.

As a result of this analysis (the area of influence represented by the shape forms), zones 2, 4, 5, 6, 9, 10, 13, and 14 of Cuenca city are not considered in the methods used. 


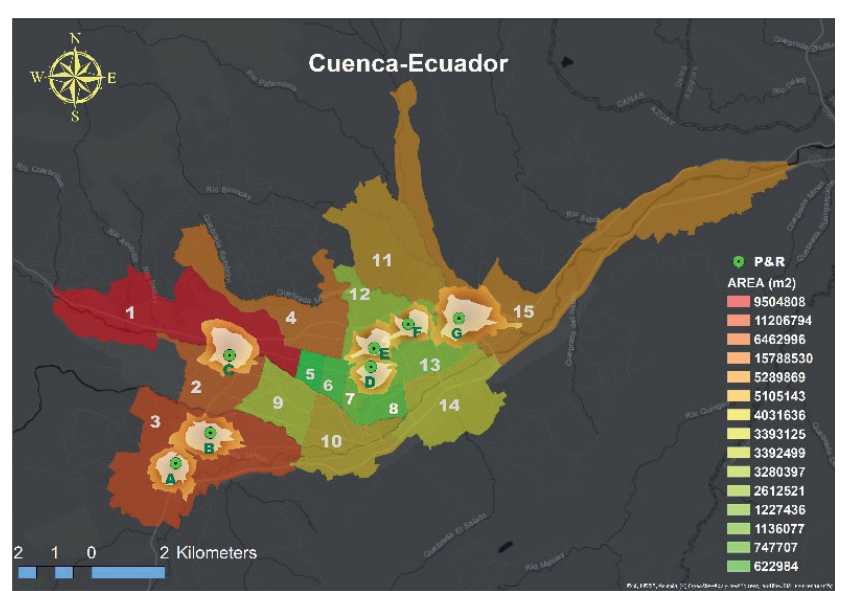

Fig. 4 Geographic information systems representation of the market method.

Table 5 Numerical results of the market area method

\begin{tabular}{lccc}
\hline ID & \multicolumn{3}{c}{ Market area } \\
P\&R & $\begin{array}{c}\text { Catchment area } \mathrm{km}^{2} \\
5 \text { minutes }\end{array}$ & $\begin{array}{c}\text { Catchment area } \mathrm{km}^{2} \\
10 \text { minutes }\end{array}$ & $\begin{array}{c}\text { Influence } \\
\text { Zones }\end{array}$ \\
\hline $\mathrm{A}$ & 0.59 & 1.39 & 3 \\
$\mathrm{~B}$ & 0.77 & 1.66 & 3 \\
$\mathrm{C}$ & 0.89 & 1.84 & 1,2 \\
$\mathrm{D}$ & 0.47 & 0.99 & 7 \\
$\mathrm{E}$ & 0.51 & 1.082 & 12 \\
$\mathrm{~F}$ & 0.88 & 1.85 & 12 \\
$\mathrm{G}$ & 1.09 & 2.63 & 15 \\
\hline
\end{tabular}

\subsection{Dynamic accessibility}

The dynamic accessibility method determines how dynamically accessible a P\&R facility is to catch potential users and how far it is from alternative facilities. This means that the catchment area in this method contains the zones composing the city. Table 6 shows fifteen zones of Cuenca city and the level of accessibility for each Park and Ride facility, where the color red represents the highest level, and orange is the lowest level of accessibility. For example, the users in zone 3 are the most likely to choose P\&R (B) and (A), while users are very unlikely to choose $P \& R(F)$ and $(G)$.
However, a certain number of users may choose P\&R (D), and a smaller group may choose P\&R (C) and (E).

Fig. 5 shows a graphical representation of the level of P\&R accessibility of the zone 3 of Cuenca, Ecuador. This answers the question of how dynamically accessible a P\&R facility is (Unlikely or Highly).

Answer: Highly-P\&R A, B; potentially-likely $P \& R D$; less probably-P\&R $C-E$, unlikely-P\&R $F-G$.

\section{Discussion}

In the cases presented above, we focused on the research of catchment areas for P\&R systems using three methods: geometric shapes, market areas, and dynamic accessibility. The results shown in Table 7 provide a set of characteristics to measure the variation and performance between each of these methods:

1. The geometric shape method utilizing the distance component to access a P\&R facility is used to calculate and study the extent of the catchment area for a P\&R facility.

2. The market area method uses GIS software and the ArcGIS Network Analyst extension to calculate and study the characteristics of the catchment area of the P\&R system by implementing a principal component of travel time.

3 . The geometry shape and market area methods present a considerable difference. The geometry shape method and its boundary area are represented as a standard polygon (parabola or circle), while the market area method and its boundary area are represented as an irregular polygon. This approach demonstrates that the catchment area of a P\&R system requires extensive and complex studies considering a set of parameters during analysis. The conclusion when comparing both methods is that an irregular polygon developed in the GIS software produces greater accuracy than a standard polygon.

Table 6 Dynamic accessibility per zone and per P\&R

\begin{tabular}{|c|c|c|c|c|c|c|c|c|c|c|c|c|c|c|c|}
\hline Zones & 1 & 2 & 3 & 4 & 5 & 6 & 7 & 8 & 9 & 10 & 11 & 12 & 13 & 14 & 15 \\
\hline \multirow{7}{*}{ 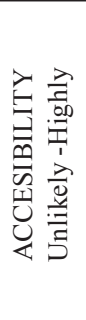 } & $\mathrm{C}$ & $\mathrm{C}$ & B & $\mathrm{F}$ & $\mathrm{E}$ & $\mathrm{E}$ & $\mathrm{E}$ & $\mathrm{E}$ & D & E & $\mathrm{G}$ & $\bar{F}$ & $\bar{E}$ & $\bar{E}$ & $\bar{G}$ \\
\hline & $\mathrm{D}$ & $\mathrm{D}$ & A & $\mathrm{E}$ & $\mathrm{F}$ & $\mathrm{F}$ & $\mathrm{F}$ & $\mathrm{F}$ & $\mathrm{C}$ & $\mathrm{D}$ & $\mathrm{F}$ & $\mathrm{G}$ & G & G & $\mathrm{F}$ \\
\hline & $\mathrm{F}$ & B & D & C & C & G & $\mathrm{G}$ & $\mathrm{G}$ & B & C & E & $\mathrm{E}$ & $\mathrm{F}$ & $\mathrm{F}$ & E \\
\hline & $\mathrm{B}$ & A & $\mathrm{C}$ & $\mathrm{G}$ & $\mathrm{D}$ & $\mathrm{C}$ & $\mathrm{D}$ & $\mathrm{D}$ & $\mathrm{A}$ & $\mathrm{F}$ & $\mathrm{C}$ & $\mathrm{C}$ & $\mathrm{C}$ & $\mathrm{B}$ & $\mathrm{C}$ \\
\hline & $\mathrm{E}$ & $\mathrm{F}$ & $\mathrm{E}$ & D & $\mathrm{G}$ & $\mathrm{D}$ & $\mathrm{C}$ & $\mathrm{C}$ & $\mathrm{E}$ & $\mathrm{G}$ & $\mathrm{D}$ & $\mathrm{D}$ & $\mathrm{D}$ & A & B \\
\hline & $\mathrm{G}$ & $\mathrm{E}$ & $\mathrm{F}$ & B & B & B & B & B & $\mathrm{F}$ & B & A & $\mathrm{B}$ & $\mathrm{B}$ & $\mathrm{D}$ & A \\
\hline & $\mathrm{A}$ & $\mathrm{G}$ & $\mathrm{G}$ & A & A & $\mathrm{A}$ & $\mathrm{A}$ & A & $\mathrm{G}$ & A & $\mathrm{B}$ & $\mathrm{Q}$ & $\mathrm{A}$ & $\mathrm{C}$ & $\mathrm{D}$ \\
\hline
\end{tabular}




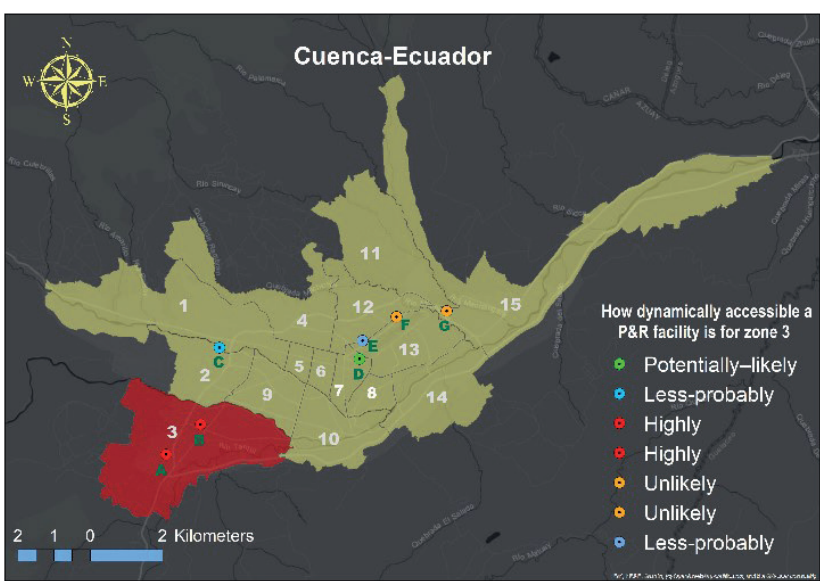

Fig. 5 Geographic information systems representation of the dynamic accessibility method

Table 7 Characteristics of the components of the catchment area of the P\&R system

\begin{tabular}{lccc}
\hline $\begin{array}{l}\text { Characteristics of the } \\
\text { components of the catchment } \\
\text { area of the P\&R system }\end{array}$ & $\begin{array}{c}\text { Geometric } \\
\text { shape }\end{array}$ & $\begin{array}{c}\text { Market } \\
\text { area }\end{array}$ & $\begin{array}{c}\text { Dynamic } \\
\text { accessibility }\end{array}$ \\
\hline $\begin{array}{l}\text { Area of the catchment area } \\
\text { Travel time }\end{array}$ & $\checkmark$ & $\checkmark$ & $\checkmark$ \\
$\begin{array}{l}\text { Influence zone approach } \\
\text { Distance parameter }\end{array}$ & $\checkmark$ & $\checkmark$ & $\checkmark$ \\
$\begin{array}{l}\text { Traffic study } \\
\text { Real traffic approach }\end{array}$ & $\checkmark$ & $\checkmark$ \\
$\begin{array}{l}\text { Real road network } \\
\text { information }\end{array}$ & & $\checkmark$ \\
\hline
\end{tabular}

4. The results suggest that the dynamic accessibility in P\&R facilities should be considered as a complex method of study. This approach allows one to understand the P\&R system and its effects on the transit of a city. Additionally, this information can be used to help the users of the P\&R system choose the nearest and least congested route to reach the facility. Accounting for more elements in the transportation system will allow a higher level of detail to be applied, thereby reducing the time spent when transferring between transportation modes.

\section{Conclusions}

P\&R facilities are a component of transport planning in the provision, operation, and administration of facilities, while for Sustainability Urban Mobility plans (SUMP), the P\&R system is a tool to achieve environmental friendliness and reduce traffic congestion in the central business district. P\&R facilities are located in different zones of a city in order to allow travelers from the outskirt areas of an urban environment to transfer to a public transportation mode to reach the CBD. The primary purpose of the catchment areas of P\&R facilities is the collection of potential demand. Therefore, calculating the catchment area and determining which methods to apply is the first step in the study of P\&R systems.

The precision of a catchment area's delineation depends directly on which method is applied. This study investigated a set of methods to calculate the catchment area of the P\&R system, particularly the geometry shape and market area methods combined with the use of Geographic Information Systems (GIS) and the ArcGIS Network Analyst extension. The geometry shape method uses two approaches to determine the boundary area of a facility. The first is the parabola method, and the second is the circle method. The ArcGIS Network Analyst extension tool, and its service area function, is utilized to examine and visualize $P \& R$ market areas. Therefore, it does not seem reasonable to assume, like some authors do, that the catchment area of a park-and-ride facility has a given prespecified shape (parabolic or otherwise). Finally, this research extended and developed a novel contribution approach: a dynamic accessibility method for the catchment areas of P\&R facilities.

The dynamic accessibility of P\&R systems was measured across Cuenca in Ecuador. This method used the data from a group of five matrices, with two metrics for distance (road network distance and shortest distance) and three for travel time (no traffic, low traffic, and high traffic). The relationship between the metrics of the matrix of travel time and each P\&R facility is considered for dynamic accessibility.

The dynamic accessibility of P\&R systems in future research will require extensive and complex studies. An elaborate study must be developed to include the destination points of the central business district. In addition, a mathematical optimization model that includes the logit choice model constraint could help calculate the real number of users of the P\&R system for each zone because the users themselves decide whether to use one of these facilities or to drive their cars.

This article is a novel contribution to research on the catchment areas of P\&R facilities. Additionally, we investigated the traditional methods and proposed a new method that can be used as a tool for planners and researchers in transport planning. We investigated the evolution, advantages, characteristics, and limitations of three methods. For this reason, the catchment areas of $P \& R$ facilities should be included in future transit accessibility studies of cities to facilitate a detailed investigation of P\&Rs in transport planning. 


\section{Acknowledgment}

The authors are grateful to the Cuenca Municipality for providing us with the data from the Sustainable Urban

\section{References}

Bahoken, F., Olteanu-Raimond, A.-M. (2013) "Designing OriginDestination Flow Matrices from Individual Mobile Phone Paths The Effect of Spatiotemporal Filtering on Flow Measurement", [pdf] In: Proceedings of the 26th International Cartographic Conference, Dresden, Germany. Available at: https://icaci.org/files/ documents/ICC_proceedings/ICC2013/_extendedAbstract/393 proceeding.pdf [Accessed: 01 May 2020]

Cairns, M. R. (1998) "The Development of Park and Ride in Scotland", Journal of Transport Geography, 6(4), pp. 295-307. https://doi.org/10.1016/S0966-6923(98)00016-7

Cao, M., Cai, B., Ma, S., Lü,G., Chen, M. (2019) "Analysis of the Cycling Flow between Origin and Destination for Dockless Shared Bicycles Based on Singular Value Decomposition", ISPRS International Journal of Geo-Information, 8(12), Article No.: 573. https://doi.org/10.3390/ijgi8120573

Carlson, K., Owen, A. (2019) "Accessibility Impacts of Park-and-Ride Systems", Transportation Research Record, 2673(9), pp. 72-82. https://doi.org/10.1177/0361198119845665

Cornejo, L., Perez, S., Cheu, R. L., Hernandez, S. (2014) "An Approach to Comprehensively Evaluate Potential Park and Ride Facilities", International Journal of Transportation Science and Technology, 3(1), pp. 1-18. https://doi.org/10.1260/2046-0430.3.1.1

Debrezion, G., Pels, E., Rietveld, P. (2009) "Modelling the joint access mode and railway station choice", Transportation Research Part E: Logistics and Transportation Review, 45(1), pp. 270-283. https://doi.org/10.1016/j.tre.2008.07.001

Duncan, M., Christensen, R. K. (2013) "An analysis of park-and-ride provision at light rail stations across the US", Transport Policy, 25, pp. $148-157$.

https://doi.org/10.1016/j.tranpol.2012.11.014

Duncan, M., Cook, D. (2014) "Is the provision of park-and-ride facilities at light rail stations an effective approach to reducing vehicle kilometers traveled in a US context?", Transportation Research Part A: Policy and Practice, 66, pp. 65-74. https://doi.org/10.1016/j.tra.2014.04.014

Esri (a) "Public Transit Analysis in ArcGIS", [online] http://transit. melindamorang.com/ [Accessed: 01 May 2019]

Esri (b) "What is GIS?", [online] Available at: https:/www.esri.com/ en-us/what-is-gis/overview [Accessed: 01 May 2020]

Fan, K.-S., Miller, E. J., Badoe, D. (1993) "Modeling Rail Access Mode and Station Choice", Transportation Research Record, 1413, pp. 49-59.

Fang, D., He, D., Chen, X.,Yu, H., Chen, K. (2017) "Optimal location of a park-and-ride system under capture rate and capacity constraints", Journal of Harbin Engineering University, 38(2), pp. 207-214. https://doi.org/10.11990/jheu.201610038

Farhan, B., Murray, A T. (2005) "A GIS-Based Approach for Delineating Market Areas for Park and Ride Facilities", Transactions in GIS, 9(2), pp. 91-108. https://doi.org/10.1111/j.1467-9671.2005.00208.x
Mobility Plan. The authors would like to thank Department of Transport Technology and Economics for their useful discussion during this study.

Farhan, B., Murray, A. T. (2008) "Siting park-and-ride facilities using a multi-objective spatial optimization model", Computers and Operations Research, 35(2), pp. 445-456. https://doi.org/10.1016/j.cor.2006.03.009

Gutsche, P., Garcia-Santiago, X., Schneider, P.-I., McPeak, K., M., NietoVesperinas, M., Burger, S. (2020) "Role of Geometric Shape in Chiral Optics", Symmetry, 12(1), Article No.: 158. https://doi.org/10.3390/sym12010158

Hanjoul, P. (1988) "Market Areas within Networks", Department of Geography, University of Louvain-la-Neuve, Louvain-la-Neuve, Belgium, Working Paper No.: 8809.

Ison, S., Mulley, C. (2014) "Introduction", In: Parking Issues and Policies, Emerald Group Publishing Limited, Bingley, pp. 1-9. https://doi.org/10.1108/S2044-994120140000005015

Li, Z.-C., Huang, H.-J., Lam, W. H. K., Wong, S. C. (2007) "A Model for Evaluation of Transport Policies in Multimodal Networks with Road and Parking Capacity Constraints", Journal of Mathematical Modelling and Algorithms, 6, pp. 239-257. https://doi.org/10.1007/s10852-006-9040-7

Liu, T. L., Huang, H. J., Yang, H., Zhang, X. (2009) "Continuum modeling of park-and-ride services in a linear monocentric city with deterministic mode choice", Transportation Research Part B: Methodological, 43(6), pp. 692-707. https://doi.org/10.1016/j.trb.2009.01.001

Ma, J., Li, H., Yuan, F., Bauer, T. (2013) "Deriving Operational OriginDestination Matrices From Large Scale Mobile Phone Data", International Journal of Transportation Science and Technology, 2(3), pp. 183-204. https://doi.org/10.1260/2046-0430.2.3.183

Mesa, J. A., Ortega, F. A. (2001) "Park-and-Ride Station Catchment Areas in Metropolitan Rapid Transit Systems", In: Pursula, M., Niittymäki, J. (eds.) Mathematical Methods on Optimization in Transportation Systems, Springer, Boston, MA, USA, pp. 81-93. https://doi.org/10.1007/978-1-4757-3357-0_5

Noel, E. C. (1988) "Park-and-Ride: Alive, Well, and Expanding in the United States", Journal of Urban Planning and Development, 114(1), pp. 2-13. https://doi.org/10.1061/(ASCE)0733-9488(1988)114:1(2)

Ortega, J., Tóth, J., Péter, T. (2019) "Estimation of parking needs at Light Rail Transit System stations", In: Horváth, G., Gaál, B., Horváth, B. (eds.) Közlekedéstudományi Konferencia Győr 2019 Conference on Transport Sciences: Alternatív-AutonómKooperatív-Komparatív Mobilitás (Tanulmánykötet), Széchenyi István Egyetem, Győr, Hungary, Paper No: 33.

Saif, M. A., Zefreh, M. M., Torok, A. (2019) "Public Transport Accessibility: A Literature Review", Periodica Polytechnica Transportation Engineering, 47(1), pp. 36-43. https://doi.org/10.3311/PPtr.12072 
See, L., Fritz, S., De Leeuw, J. (2013) "The Rise of Collaborative Mapping: Trends and Future Directions", ISPRS International Journal of Geo-Information, 2(4), pp. 955-958. https://doi.org/10.3390/ijgi2040955

Spillar, R. J. (1997) "Park-and-Ride Planning and Design Guidelines", Parsons Brinckerhoff Inc., New York, NY, USA.

Spillar, R. J. (1999) "Smart Parks: The Next Generation in Park-AndRide Facilities", Parking, 38(2), pp. 30-31.

Stieffenhofer, K. E., Barton, M., Gayah, V. V. (2016) "Assessing Parkand-Ride Efficiency and User Reactions to Parking Management Strategies", Journal of Public Transportation, 19(4), pp. 75-92. https://doi.org/10.5038/2375-0901.19.4.5

Syed Adnan, S. A. A.,Kadar Hamsa, A. A. (2013) "Evaluating the Parking Demand at Park and Ride Facility at Putrajaya Public Transportation Terminal", [pdf] In: Proceedings of the Eastern Asia Society for Transportation Studies, 9, Article ID: P279. Available at: http://www.easts.info/on-line/proceedings/vol9/PDF/ P279.pdf [Accessed: 01 May 2020]

Tam, M. L., Lam, W. H. K. (2000) "Maximum car ownership under constraints of road capacity and parking space", Transportation Research Part A: Policy and Practice, 34(3), pp. 145-170. https://doi.org/10.1016/S0965-8564(98)00070-6

Tang, H. T., Lee, Y. M. (2016) "The Making of Sustainable Urban Development: A Synthesis Framework", Sustainability, 8(5), Article No.: 492 https://doi.org/10.3390/su8050492

Turnbull, K. F. (1995) "Effective Use of Park-and-Ride Facilities", National Academy Press, Washington, DC, USA.

Veenendaal, B. (2016) "Eras of Web Mapping Developments: Past, Present and Future", In:XXIII ISPRS Congress, Prague, Chech Republic, pp. 247-252.

https://doi.org/10.5194/isprsarchives-XLI-B4-247-2016

Veenendaal, B., Brovelli, M. A., Li, S. (2017) "Review of Web Mapping: Eras, Trends and Directions", ISPRS International Journal of GeoInformation, 6(10), Article No.: 317. https://doi.org/10.3390/ijgi6100317
Vincent, M. (2007) "Park and ride: Characteristics and demand forecasting", Land Transport New Zealand, Wellington, New Zeland, Booz Allen Hamilton (New Zealand) Ltd., Auckland, New Zeland, Rep. 328.

Xiang, Q., Wu, Q. (2019) "Tree-Based and Optimum Cut-Based OriginDestination Flow Clustering", ISPRS International Journal of GeoInformation, 8(11), Article No.: 477. https://doi.org/10.3390/ijgi8110477

Xu, Z., Cui, G., Zhong, M., Wang, X. (2019) "Anomalous Urban Mobility Pattern Detection Based on GPS Trajectories and POI Data", ISPRS International Journal of Geo-Information, 8(7), Article No.: 308. https://doi.org/10.3390/ijgi8070308

Yang, H., Wang, J. Y. T. (2002) "Park-And-Ride Location And Price Optimisation in a Linear Monocentric City With Logit-Based Mode Choice" In: Transportation in the Information Age: Proceedings of the 7th Conference of Hong Kong Society for Transportation Studies, Hong Kong, China, pp. 345-354.

Young, M., Blainey, S. (2018) "Railway Station Choice Modelling: A Review of Methods and Evidence", Transport Reviews, 38(2), pp. 232-251. https://doi.org/10.1080/01441647.2017.1326537

Yajing, H., Yang, X. K., Yue, C. X. (2013)"Rail Transit-Based Planning and Design of Park-and-Ride Facilities in Beijing", In: Transportation Research Board 92nd Annual Meeting, Washington, DC, USA, Paper number: 13-2493.

Zagel, B. (2006) "ArcGIS Network Analyst" GIS Business, 1(2), pp. 42-45.

Zijlstra, T., Vanoutrive, T., Verhetsel, A. (2015) "A meta-analysis of the effectiveness of park-and-ride facilities", European Journal of Transport and Infrastructure Research, 15(4), pp. 597-612. https://doi.org/10.18757/ejtir.2015.15.4.3099 